\title{
Rickettsia parkeri: A RICKETTSIAL PATHOGEN TRANSMITTED BY TICKS IN ENDEMIC AREAS FOR SPOTTED FEVER RICKETTSIOSIS IN SOUTHERN URUGUAY
}

José M. VenZAL(1), Agustín ESTRADA-PEÑA(2), Aránzazu PORTILlO(3), Atilio J. MANGOLD(4), Oscar CASTRO(5), Carlos G. DE SOUZA(5), María L. FÉLIX(1), Laura PÉREZ-MARTÍNEZ(3), Sonia SANTIBÁNEZ(3) \& José A. OTEO(3)

\begin{abstract}
SUMMARY
At first Rickettsia conorii was implicated as the causative agent of spotted fever in Uruguay diagnosed by serological assays. Later Rickettsia parkeri was detected in human-biting Amblyomma triste ticks using molecular tests. The natural vector of $R$. conorii, Rhipicephalus sanguineus, has not been studied for the presence of rickettsial organisms in Uruguay. To address this question, 180 $R$. sanguineus from dogs and 245 A. triste from vegetation (flagging) collected in three endemic localities were screened for spotted fever group (SFG) rickettsiosis in southern Uruguay. Tick extracted DNA pools were subjected to PCR using primers which amplify a fragment of the rickettsial gltA gene. Positive tick DNA pools with these primers were subjected to a second PCR round with primers targeting a fragment of the ompA gene, which is only present in SFG rickettsiae. No rickettsial DNA was detected in $R$. sanguineus. However, DNA pools of $A$. triste were found to be positive for a rickettsial organism in two of the three localities, with prevalences of $11.8 \%$ to $37.5 \%$ positive pools. DNA sequences generated from these PCR-positive ticks corresponded to $R$. parkeri. These findings, joint with the aggressiveness shown by $A$. triste towards humans, support previous data on the involvement of $A$. triste as vector of human infections caused by $R$. parkeri in Uruguay.
\end{abstract}

KEYWORDS: Rhipicephalus sanguineus; Amblyomma triste; Rickettsia parkeri; Spotted fever group (SFG); Uruguay.

\section{INTRODUCTION}

In the beginning of the $21^{\text {st }}$ century, Rickettsia rickettsii, the agent of the Rocky Mountain spotted fever (RMSF) was the only Rickettsia known in ticks collected in South America ${ }^{11}$. This organism has been detected in Argentina, Brazil, Canada, Colombia, Costa Rica, the USA, México and Panama, and causes fatal cases in the majority of these countries $^{11}$. Based on development of new molecular biology tools, other rickettsiae have been described in ticks from South America during the last few years ${ }^{11,26}$. The history of spotted fever group (SFG) rickettsiosis in Uruguay is rather complex. The first three autochthonous cases of human rickettsiosis were diagnosed by Indirect Fluorescent Antibody Test (IFAT) ${ }^{5}$. Rickettsia conorii, the agent of Mediterranean spotted fever (MSF) was implicated as the causative agent, and the tick Amblyomma maculatum was found attached to at least one of the patients ${ }^{5}$. The natural vector and potential reservoir of $R$. conorii in the Old World is the $R$. sanguineus group, implicated in the transmission of other Rickettsia species affecting humans ${ }^{23,34}$. In Argentina, Rickettsia massiliae was detected in $R$. sanguineus collected in the city of Buenos Aires, and recently a human case of $R$. massiliae infection has been confirmed in the same country ${ }^{3,9}$.

In Uruguay, $R$. sanguineus is the second most frequently identified tick involved in bites of humans ${ }^{31}$. However, the infection by $R$. conorii has been neither reported in autochthonous form in the New World nor associated to ticks of the genus Amblyomma ${ }^{19,23}$. In Uruguay new human cases have been confirmed suggesting that Amblyomma triste tick is the vector (not Amblyomma maculatum, a tick species absent in Uruguay) and making the disease considered as "endemic and emergent" in this country ${ }^{4}$.

Rickettsia parkeri has been reported as a pathogen of humans in the United States, where it is transmitted by A. maculatum ${ }^{17}$. A. triste has been found infected with $R$. parkeri in Uruguay ${ }^{16,32}$. In addition to the USA and Uruguay, $R$. parkeri has been also detected in A. triste from Brazil, Argentina and in Amblyomma tigrinum from Bolivia ${ }^{14,25,30}$. Recently in Argentina, nine cases of SFG rickettsiosis associated to $R$. parkeri infection have been reported. Two of them were confirmed by $\mathrm{PCR}^{21}$. In Uruguay, new cases of human rickettsiosis confirmed by serological antibody-absorption tests with purified antigens of $R$. parkeri associated with immunofluorescence assays indicated that the patients were infected by $R$. parkeri ${ }^{6}$.

A. triste is the tick species most frequently implicated in human bites in Uruguay and it is particularly aggressive ${ }^{31}$.

The main aim of this study was to evaluate the prevalence of Rickettsia spp. in ticks collected in a region considered as endemic for human SFG rickettsiosis in Uruguay ${ }^{4}$.

(1) Departamento de Parasitología Veterinaria, Facultad de Veterinaria, Universidad de la República, Regional Norte, Salto, Uruguay.

(2) Facultad de Veterinaria, Universidad de Zaragoza, Zaragoza, Spain.

(3) Área de Enfermedades Infecciosas, Hospital San Pedro - Centro de Investigación Biomédica de La Rioja, Logroño, La Rioja, Spain

(4) Estación Experimental Agropecuaria Rafaela. Instituto Nacional de Tecnología Agropecuaria (INTA), Rafaela, Santa Fe, Argentina.

(5) Departamento de Parasitología Veterinaria, Facultad de Veterinaria, Universidad de la República, 11600 Montevideo, Uruguay.

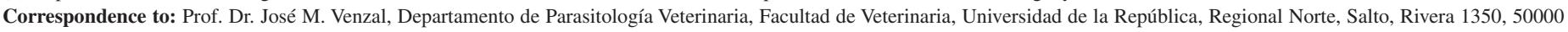
Salto, Uruguay. Tel.: +598.473.28839. E-mail: dpvuru@ hotmail.com 
VENZAL, J.M.; ESTRADA-PEÑA, A.; PORTILLO, A.; MANGOLD, A.J.; CASTRO, O.; DE SOUZA, C.G.; FÉLIX, M.L.; PÉREZ-MARTÍNEZ, L.; SANTIBÁNEZ, S. \& OTEO, J.A. Rickettsia parkeri: a rickettsial pathogen transmitted by ticks in endemic areas for spotted fever rickettsiosis in southern Uruguay. Rev. Inst. Med. Trop. Sao Paulo, 54(3): 131-4, 2012.

\section{MATERIALS AND METHODS}

Studied area and collection of ticks. A total of 245 A. triste ticks (155 females and 90 males) were collected from August to October (adult activity season) 2004, by flagging on vegetation in three suburban areas in southern Uruguay, two of them in Canelones county (Toledo Chico, at $34^{\circ} 44^{\prime} \mathrm{S}, 56^{\circ} 06^{`} \mathrm{~W}$, and Escuela Militar de Aeronáutica - EMA, at $34^{\circ} 44^{\prime} \mathrm{S}, 55^{\circ} 58^{`} \mathrm{~W}$ ), and the other one in Montevideo county (Villa García, at $34^{\circ} 46^{\prime} \mathrm{S}, 56^{\circ} 02^{\prime} \mathrm{W}$ ) (Fig. 1). Details of captures of questing ticks are included in Table 1. Furthermore, 180 R. sanguineus ticks (88 females, 64 males, 24 nymphs and four larvae) were collected on dogs in urban and suburban areas from November 2000 to February 2005 in Montevideo and Canelones counties. These samples were obtained after the examination of dogs in rural areas and in private veterinary clinics, as well as from arthropods submitted to the Department of Parasitology, Veterinary Faculty, Montevideo (Uruguay) for diagnosis.

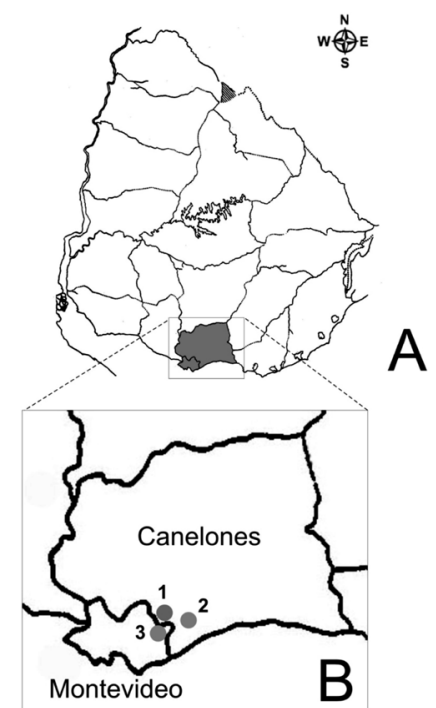

Fig. 1. - A - Map of Uruguay. B - Map of study area magnified, localities of captures: 1. Toledo Chico, Canelones county. 2. Escuela Militar de Aeronáutica, Canelones county. 3. Villa García, Montevideo county.

Ticks were immediately fixed and stored in tubes containing ethanol $70^{\circ}$ to preserve DNA, and identified using standard taxonomic keys ${ }^{1,7}$.

DNA extraction and polymerase chain reaction (PCR) assays. Ticks were rinsed with distilled water for 10 minutes and dried on sterile filter paper in a laminar-flow hood. Specimens were longitudinally cut, and the DNA of five "half-tick" pools was extracted using the JETQUICK Tissue DNA Spin Kit (GENOMED). The other half of each tick was stored for other studies on pathogen and symbiont.

Specimens were processed by PCR assays using primers CS-78 (forward) (5'-GCAAGTATCGGTGAGGATGTAAT-3') and CS-323 (reverse) (5'-GCTTCCTTAAAATTCAATAAATCAGGAT-3'), which amplify a $401 \mathrm{bp}$ fragment of the citrate synthase gene ( $\mathrm{gltA}$ ), previously reported as adequate for detection of Rickettsia spp. ${ }^{12}$. PCR cycling conditions were as follows: an initial three min. denaturation cycle at $95^{\circ} \mathrm{C}$ followed by 40 cycles of denaturation $\left(95^{\circ} \mathrm{C}\right.$ for $\left.15 \mathrm{~s}\right)$, annealing $\left(48^{\circ} \mathrm{C}\right.$ for $30 \mathrm{~s})$, and extension $\left(72{ }^{\circ} \mathrm{C}\right.$ for $\left.30 \mathrm{~s}\right)$ with a final seven min extension at $72{ }^{\circ} \mathrm{C}$. Distilled water and DNA from Rickettsia slovaca (a rickettsial species not present in Uruguay to minimize contamination risks) were used as negative and positive controls, respectively. Ten microliters of the PCR product were separated by electrophoresis in a $1 \%$ agarose gel, stained with ethidium bromide, and examined by UV transillumination.

Tick DNA pools found to be positive with primers CS-78 and CS-323 ( $g l t A$ ) were subjected to a second PCR round with primers $\operatorname{Rr} 190.70 \mathrm{p}$ (forward) (5'-ATGGCGAATATTTCTCCAAAA-3') and Rr190.701n (reverse) (5'-GTTCCGTTAATGGCAGCATCT-3'), which amplify a 631 bp fragment of the $o m p A$ gene ${ }^{22}$. Conditions for these procedures were an initial three min denaturation cycle at $95^{\circ} \mathrm{C}$, followed by 40 cycles of denaturation $\left(95^{\circ} \mathrm{C}\right.$ for $\left.20 \mathrm{~s}\right)$, annealing $\left(46^{\circ} \mathrm{C}\right.$ for $\left.30 \mathrm{~s}\right)$, and extension $\left(63^{\circ} \mathrm{C}\right.$ for $60 \mathrm{~s}$ ) with a final seven min extension at $72{ }^{\circ} \mathrm{C}$. Controls were as previously described.

Sequencing and phylogenetic analysis. Nucleotide sequences of PCR products for $g l t A$ and $o m p A$ were compared with those available in GenBank using Basic Local Alignment Search Tool (BLAST) (http:// www.ncbi.nlm.nih.gov/blast). Phylogenetic analyses were conducted using MEGA version 4.029. A Neighbor-Joining ${ }^{24}$ tree was generated using Tajima-Nei method ${ }^{28}$ and gaps were excluded in the pairwise comparison. Support for the NJ topology was tested by bootstrapping over 1,000 replications $^{8}$.

\section{RESULTS}

A total of 49 pools of A. triste ( 31 pools of females and 18 of males) were analyzed. Eight out of 49 pools showed positive PCR results for gltA and ompA genes. The prevalence of Rickettsia in ticks using PCR primers CS-78 / CS-323 and Rr190.70p / Rr190.701n is shown in Table 1, and expressed as percentage and minimum infection rate (MIR) or the minimum percentage of ticks in a pool with detectable Rickettsia. This

Table 1

Adults of Amblyomma triste ticks collected in southern Uruguay and percentage and minimum infection rate (MIR) of positive A. triste pools obtained by PCR using primers for gltA and ompA gene for Rickettsia species

\begin{tabular}{|c|c|c|c|c|c|}
\hline \multirow{2}{*}{ Locality } & \multicolumn{5}{|c|}{ Amblyomma triste ticks } \\
\hline & $\mathrm{N}^{\mathrm{a}}$ & Female pools & Male pools & Total pools & MIR \\
\hline EMA & 85 (60F, 25M) & $0 / 12(0.0 \%)^{\mathrm{b}}$ & $2 / 5(40.0 \%)$ & $2 / 17(11.8 \%)$ & $2 / 85(2.3 \%)$ \\
\hline Toledo Chico & $80(55 \mathrm{~F}, 25 \mathrm{M})$ & $3 / 11(27.3 \%)$ & $3 / 5(60.0 \%)$ & $6 / 16(37.5 \%)$ & $6 / 80(7.5 \%)$ \\
\hline Villa García & $80(40 \mathrm{~F}, 40 \mathrm{M})$ & $0 / 8(0.0 \%)$ & $0 / 8(0.0 \%)$ & $0 / 16(0.0 \%)$ & $0 / 80(0.0 \%)$ \\
\hline Total & $245(155 \mathrm{~F}, 90 \mathrm{M})$ & $3 / 31(9.7 \%)$ & $5 / 18(27.8 \%)$ & $8 / 49(16.3 \%)$ & $8 / 145(5.5 \%)$ \\
\hline
\end{tabular}

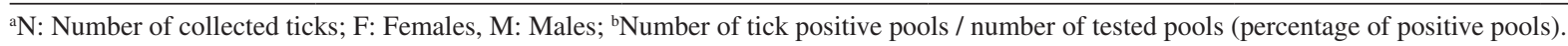





Rickettsia parkeri: a rickettsial pathogen transmitted by ticks in endemic areas for spotted fever rickettsiosis in southern Uruguay. Rev. Inst. Med. Trop. Sao Paulo, 54(3): 131-4, 2012.

calculation is based on the assumption that a PCR-positive pool contains only one positive tick ${ }^{2,13}$. It is interesting to note the high variability in infection rates of questing ticks between localities, with a maximum of $7.5 \%$ MIR and $37.5 \%$ infected pools in Toledo Chico. The ompA nucleotide sequence (462 bp) was deposited in Genbank (accession number JN664898), and it was named $R$. parkeri Canelones. The alignment of our sequence with 19 partial ompA sequences from SFG rickettsiae available in GenBank resulted in a total of 450 sites including gaps. Our sequence grouped with sequences of $R$. parkeri obtained in several countries and $R$. parkeri (strain Cooperi) and Rickettsia sp. for Amblyomma nodosum in the phylogenetic tree based on these partial ompA sequences, but it is separated from other species of Rickettsia detected in ticks in South America, as well as R. conorii (Fig. 2).



Fig. 2 - Phylogenetic tree based on partial ompA gene sequences (450 bp) showing the position of Rickettsia parkeri Canelones and selected members of the genus Rickettsia. The evolutionary history was inferred using the Neighbor-Joining method. The evolutionary distances were computed using the Tajima-Nei method and are in the units of the number of base substitutions per site. Codon positions included were $1^{\text {st }}+2^{\text {nd }}+3^{\text {rd }}+$ Noncoding. Numbers represent the percentage of 1000 bootstrap replicates supporting each branch. The tree is drawn to scale, with branch lengths in the same units as those of the evolutionary distances used to infer the phylogenetic tree. The GenBank accession number for each sequence is indicated.

Rickettsial DNA was not found in any of the 36 pools prepared with the 180 R. sanguineus ticks, using CS-78 and CS-323 primers for gltA gene.

\section{DISCUSSION}

$R$. parkeri has been the only pathogen detected in A. triste ticks collected in a region considered endemic for human SFG rickettsiosis in Uruguay. In our study, all $R$. sanguineus tested showed negative PCR results, and neither $R$. conorii nor any other Rickettsia species was detected. Nevertheless, our data do not rule out that the population of $R$. sanguineus of Uruguay harbors Rickettsia spp. These findings further support that $R$. parkeri is the most frequently found SFG rickettsia circulating in this region, $A$. triste being the main vector. It seems that $R$. parkeri has been a neglected pathogen in wide areas of the American continent. It was unequivocally associated to a case of human disease in Virginia (USA) and proved to be transmitted by $A$. maculatum ${ }^{17}$. Since the first association with human disease, more cases have been confirmed in humans in Virginia, Mississippi and probably other states of the USA ${ }^{18,35}$. A recent survey on the range of $R$. parkeri in the USA shows that it is within the known range of the vector A. maculatum with prevalence varying according to the different states, averaging $11 \%$ of collected ticks in Florida, Georgia, Kentucky, Mississippi and Oklahoma ${ }^{27}$. Additional work carried out in Uruguay, Brazil and Argentina demonstrated variable rates of infection by $R$. parkeri (2.5-9.7\%) in A. triste, also suggesting that $R$. parkeri may be relatively common in populations of $A$. triste ${ }^{14,25,32}$. By comparison, prevalence of infection of tick vectors with $R$. rickettsii is typically much lower, from $0.05 \%$ to $1.3 \%$, as determined by surveys in the USA and Brazil ${ }^{20,27}$.

The reasons for differences in tick infection rates among the three studied localities in this work are unknown. All three regions are socially and ecologically similar and are in an endemic area for rickettsiosis.

The first reports implicating $R$. conorii as the etiological agent of human rickettsiosis in the area of study are unsupported by our results. Previous studies on human cases in Uruguay seem to be biased due to crossed reactions using a commercial IFAT kit ${ }^{5}$. To date, autochthonous cases of $R$. conorii infection have not been confirmed in the Americas ${ }^{19,23}$.

Previous efforts to detect Ehrlichia spp. and Anaplasma spp. DNA by PCR in both $R$. sanguineus and A. triste in the same area were unsuccessful ${ }^{33}$.

Recent research has pointed out the presence of different strains of $R$. parkeri in some domestic and wild animals in Brazil, in areas where A. triste is absent ${ }^{10,15,26}$. These studies indicate that other tick species that replace A. triste in areas of Brazil (such as Amblyomma dubitatum, A. nodosum and A. ovale) might be involved in the transmission of this pathogen. Of these three ticks species only A. dubitatum is recorded for Uruguay. Further assessment is required to understand the role of other tick species in the spread and maintenance of $R$. parkeri in the Neotropics.

\section{RESUMEN}

\section{Rickettsia parkeri: patógeno rickettsial transmitido por garrapatas en áreas endémicas de rickettsiosis por fiebre manchada en el sur de Uruguay}

Inicialmente, Rickettsia conorii fue señalada como el agente causal de la fiebre manchada en Uruguay, diagnosticada mediante pruebas serológicas. Posteriormente, Rickettsia parkeri fue detectada mediante técnicas moleculares en garrapatas Amblyomma triste colectadas sobre humanos. El vector natural de $R$. conorii, Rhipicephalus sanguineus, no ha sido estudiado en cuanto a rickettsias en Uruguay. Para abordar este tema, $180 \mathrm{R}$. sanguineus fueron colectados sobre perros y $245 \mathrm{~A}$. triste sobre vegetación en tres localidades consideradas endémicas para fiebres manchadas en el sur de Uruguay. El ADN de las garrapatas fue extraído en pools y sometido a una primera PCR utilizando cebadores que amplifican un fragmento del gen $g l t A$, presente en prácticamente todas las especies de Rickettsia. Las muestras positivas fueron sometidas a una segunda PCR con cebadores que amplifican un fragmento del gen ompA, presente sólo en rickettsias del grupo de las fiebres manchadas (GFM). No se detectó ADN rickettsial en $R$. sanguineus. Sin embargo, muestras de A. triste fueron positivas a rickettsiales en dos de las tres localidades estudiadas, con prevalencias de pools positivos del 11.8 y $37.5 \%$ respectivamente. La 
VENZAL, J.M.; ESTRADA-PEÑA, A.; PORTILLO, A.; MANGOLD, A.J.; CASTRO, O.; DE SOUZA, C.G.; FÉLIX, M.L.; PÉREZ-MARTÍNEZ, L.; SANTIBÁNEZ, S. \& OTEO, J.A. Rickettsia parkeri: a rickettsial pathogen transmitted by ticks in endemic areas for spotted fever rickettsiosis in southern Uruguay. Rev. Inst. Med. Trop. Sao Paulo, 54(3): 131-4, 2012.

secuenciación del ADN evidenció la presencia de $R$. parkeri. Basados en estos resultados junto a los anteriores y la agresividad de $A$. triste hacia los humanos, se concluye que esta garrapata es vector de rickettsiosis humana por $R$. parkeri en Uruguay.

\section{ACKNOWLEDGMENTS}

This work was supported by the Programa Iberoamericano de Ciencias y Tecnologia para el Desarrollo (CYTED) to Red Iberoamericana para la Investigación y Control de las Enfermedades Rickettsiales (RIICER). We thank Dr. Marcelo B. Labruna (USP) for critical comments on the paper.

\section{REFERENCES}

1. Barros-Battesti DM, Arzua M, Bechara GH. Carrapatos de importância médicoveterinária da Região Neotropical: um guia ilustrado para identificação de espécies. São Paulo: Vox/ICTTD-3/Butantan; 2006.

2. Burket CT, Vann CN, Pinger RR, Chatot CL, Steiner FE. Minimum infection rate of Amblyomma americanum (Acari:Ixodidae) by Ehrlichia chaffeensis (Rickettsiales: Ehrlichieae) in southern Indiana. J Med Entomol. 1998;35:653-9.

3. Cicuttin GL, Rodríguez Vargas M, Jado I, Anda P. Primera detección de Rickettsia massiliae en la ciudad de Buenos Aires. Resultado preliminares. Rev Argent Zoon. 2004;1:8-10.

4. Conti-Díaz IA. Rickettsiosis por Rickettsia conorii (fiebre botonosa del Mediterráneo o fiebre de Marsella). Estado actual en Uruguay. Rev Med Uruguay. 2001;17:119-24.

5. Conti-Díaz IA, Rubio I, Somma Moreira RE, Pérez Bórmida G. Rickettsiosis cutáneo ganglionar por Rickettsia conorii en el Uruguay. Rev Inst Med Trop Sao Paulo. $1990 ; 32: 313-8$

6. Conti-Díaz IA, Moraes-Filho J, Pacheco RC, Labruna, MB. Serological evidence of Rickettsia parkeri as etiological agent of rickettsiosis in Uruguay. Rev Inst Med Trop S Paulo. 2009;51:337-9.

7. Estrada-Peña A, Venzal JM, Mangold AJ, Cafrune MM, Guglielmone AA. The Amblyomma maculatum Koch, 1844 (Acari: Ixodidae: Amblyomminae) tick group: diagnostic characters, description of the larva of A. parvitarsum Neumann, 1901, 16S rDNA sequences, distribution and hosts. Syst Parasitol. 2005;60:99-112.

8. Felsenstein J. Confidence limits on phylogenies: an approach using the bootstrap. Evolution. 1985;39:783-91.

9. García-García JC, Portillo A, Núñez MJ, Santibáñez S, Castro B, Oteo JA. A patient from Argentina infected with Rickettsia massiliae. Am J Trop Med Hyg. 2010;82:691-2.

10. Horta MC, Labruna MB, Pinter A, Linardi PM, Schumaker TTS. Rickettsia infection in five areas of the State of São Paulo, Brazil. Mem Inst Oswaldo Cruz. 2007;102:793-801.

11. Labruna MB. Ecology of Rickettsia in South America. Ann NY Acad Sci. 2009;1166:156-66.

12. Labruna MB, Whitworth $\mathrm{T}$, Horta MC, Bouyer DH, McBride JW, Pinter A, et al. Rickettsia species infecting Amblyomma cooperi ticks from an area in State of São Paulo, Brazil, where Brazilian spotted fever is endemic. J Clin Microbiol. 2004;42:90-8.

13. Labruna MB, Whitworth T, Bouyer DH, McBride JW, Camargo LMA, Camargo EP, et al. Rickettsia bellii and Rickettsia amblyommii in Amblyomma ticks from the State of Rondonia, Western Amazon, Brazil. J Med Entomol. 2004;41:1073-81.

14. Nava S, Elshenawy Y, Eremeeva ME, Sumner JW, Mastropaolo M, Paddock CD. Rickettsia parkeri in Argentina. Emerg Infect Dis. 2008;14:1894-7.

15. Ogrzewalska M, Pacheco R, Uezu A, Richtzenhain LJ, Ferreira F, Labruna MB. Rickettsial infection in Amblyomma nodosum ticks (Acari: Ixodidae) from Brazil. Ann Trop Med Parasitol. 2009;103:413-25.
16. Pacheco RC, Venzal JM, Richtzenhain LJ, Labruna MB. Rickettsia parkeri in Uruguay. Emerg Infect Dis. 2006;12:1804-5.

17. Paddock CD, Sumner JW, Comer JA, Zaki SR, Goldsmith CS, Goddard J, et al. Rickettsia parkeri: a newly recognized cause of spotted fever Rickettsiosis in the United States. Clin Infect Dis. 2004;38:805-11.

18. Paddock CD, Finley RW, Wright CS, Robinson HN, Schrodt BJ, Lane CC, et al. Rickettsia parkeri rickettsiosis and its clinical distinction from Rocky Mountain spotted fever. Clin Infect Dis. 2008;47:1188-96

19. Parola P, Paddock CD, Raoult D. Tick-borne rickettsioses around the world: emerging diseases challenging old concepts. Clin Microbiol Rev. 2005;18:719-56.

20. Pinter A, Labruna MB. Isolation of Rickettsia rickettsii and Rickettsia bellii in cell culture from the tick Amblyomma aureolatum in Brazil. Ann N Y Acad Sci. 2006;1078:523-9.

21. Romer Y, Seijo AC, Crudo F, Nicholson WL, Varela-Stokes A, Lash RR, et al Rickettsia parkeri Rickettsiosis, Argentina. Emerg Infect Dis. 2011;17:1169-73.

22. Roux V, Fournier P, Raoult D. Differentiation of spotted fever group rickettsiae by sequencing and analysis of restriction fragment length polymorphism of PCR-amplified DNA of the gene encoding the protein rOmpA. J Clin Microbiol. 1996;34:2058-65.

23. Rovery C, Raoult D. Rickettsia conorii infections (Mediterranean spotted fever, Israel spotted fever, Indian tick typhus, Astrakhan fever). In: Raoult D, Parola P, editors. Rickettsial diseases. New York: Informa Healthcare USA; 2007. p. 125-137.

24. Saitou N, Nei M. The neighbor-joining method: a new method for reconstructing phylogenetic trees. Mol Biol Evol. 1987;4:406-25.

25. Silveira I, Pacheco RC, Szabó MPJ, Ramos HGC, Labruna MB. Rickettsia parkeri in Brazil. Emerg Infect Dis. 2007;13:1111-3.

26. Spolidorio MG, Labruna M, Mantovani E, Brandao P, Richtzenhain L, Yoshinari N Novel spotted fever group rickettsiosis, Brazil. Emerg Infect Dis. 2010;16:521-3.

27. Sumner JW, Durden LA, Goddard J, Stromdahl EY, Clark KL, Reeves WK, et al Gulf coast ticks (Amblyomma maculatum) and Rickettsia parkeri, United States. Emerg Infect Dis. 2007;13:751-3.

28. Tajima F, Nei M. Estimation of evolutionary distance between nucleotide sequences Mol Biol Evol. 1984;1:269-85.

29. Tamura K, Dudley J, Nei M, Kumar S. MEGA4: molecular evolutionary genetics analysis (MEGA) software version 4.0. Mol Biol Evol. 2007;24:1596-9.

30. Tomassone L, Conte, V, Parrilla G, De Meneghi D. Rickettsia infection in dogs and Rickettsia parkeri in Amblyomma tigrinum ticks, Cochabamba Department, Bolivia. Vector Borne Zoonotic Dis. 2010;10:953-8.

31. Venzal JM, Guglielmone AA, Estrada-Peña A, Cabrera, PA, Castro O. Ticks (Ixodida: Ixodidae) parasitising humans in Uruguay. Ann Trop Med Parasit. 2003;97:769-72.

32. Venzal JM, Portillo A, Estrada-Peña A, Castro O, Cabrera PA, Oteo JA. Rickettsia parkeri in Amblyomma triste from Uruguay. Emerg Infect Dis. 2004;10:1493-5.

33. Venzal JM, Estrada-Peña A, Castro O, de Souza CG, Portillo A, Oteo JA. Study on seasonal activity in dogs and ehrlichial infection in Rhipicephalus sanguineus (Latreille, 1806) (Acari: Ixodidae) from southern Uruguay. Parasitol Latinoam. 2007;62:23-6.

34. Walker JB, Keirans JE, Horak IG. The genus Rhipicephalus (Acari: Ixodidae): a guide to the brown ticks of the world. Cambridge: Cambridge University Press; 2000.

35. Whitman TJ, Richards AL, Paddock CD, Tamminga CL, Sniezek PJ, Jiang J, et al Rickettsia parkeri infection after tick bite, Virginia. Emerg Infect Dis. 2007;13:334-6.

Received: 12 September 2011

Accepted: 20 March 2012 